\title{
Entrepreneurship as Career Choice for University Students in Medan
}

\author{
Yasmin Chairunisa Muchtar \\ Department of Management \\ University of Sumatera Utara \\ Medan, Indonesia
}

\author{
Inneke Qamariah \\ Department of Management \\ University of Sumatera Utara \\ Medan, Indonesia
}

\begin{abstract}
One way to reduce unemployment is by creating jobs through entrepreneurship. Entrepreneurship can improve the economy of the surrounding community, which will broadly encourage the Indonesian economy. In this case, students, the most potential employer, after completing the education will face career selection decision, especially as an individual who must meet the needs of his life. Therefore, we conduct this research to analyze the influence of self-efficacy, personality, emotional intelligence, intellectual abuse effect toward student career selection. This study will not only analyze the role of entrepreneurial environment in moderating the influence of selfefficacy, personality, emotional intelligence, intellectual intelligence towards students' intention in taking up entrepreneurship, but also analyze the relationship between selfefficacy variables, personality, intellectual intelligence, entrepreneurial environment to student decisions in choosing entrepreneurship as career choice , as well as designing a career selection model entrepreneurship college students in the city of Medan. Samples in this study are amounted to 334 people who came from the University of Sumatera Utara, University of Medan Area and the College of Ilmu Ekonomi Harapan in the Medan city
\end{abstract}

Keywords: career selection, self efficacy, personality, emotional intelligence, intellectual intelligence

\section{INTRODUCTION}

Unemployment in Indonesia like every other countries is a very critical issue. Based on table 1.1, data from the Central Bureau of Statistics (2016) unemployment rate of freshgraduates have increased from year to year.

This condition is generally disturbing the government and the University in particular. Because university freshgraduates should be the most potential workforce compared to graduates from other education level. High level of unemployment increases the potential of social problems such as poverty and criminality.

One of the ways to reduce unemployment is by creating jobs through entrepreneurship. Entrepreneurship can improve the economy of the surrounding community, which will broadly encourage the Indonesian economy. Therefore it takes a lot of entrepreneurs to support the economic sector in Indonesia. However, the number of entrepreneurs in Indonesia during 2015 is only around $1.65 \%$ of the population, far behind compared to neighboring countries such as Singapore at $7 \%$, Malaysia at $5 \%$ and Thailand at $4 \%$ (www.republika.co.id).
People still consider being an entrepreneur are full of risks, uncertainties, obstacles and difficulties in dealing with the licensing process in establishing a new business. This is one of the challenges in increasing the number of entrepreneurs in Indonesia.

There are many factors that affects the career choices of a fresh-graduates who needs to fulfill his needs. Basically, one will select a career suitable with his passion, personality, ability and background. In fact, one will choose a career that allows him to utilize his competency and ability in expressing his value.

One's career choices depend on the personality traits of a person and how one has perceived a particular job [1]. In addition to personality traits, self-efficacy also influences one's career choices. Individuals with high self-efficacy values tend to try harder to master challenges in difficult situations, show persistence in facing obstacles, respond to negative feedbacks by improving effort and motivation, setting more challenging goals, and work harder and longer to achieve it [2]. Bandura's statement explains so well the situation faced by someone in entrepreneurship.

This study aims to analyze:

1. The influence of self-efficacy variables, emotional intelligence, entrepreneurship intentions towards the selection of student's careers.

2. The role of family environment in moderating the influence of self-efficacy, emotional intelligence, entrepreneurship intentions towards student's career selection.

3. The relationship between self-efficacy variables, emotional intelligence, entrepreneurship intentions, family environment to student decisions in choosing entrepreneurship as a career choice.

\section{LITERATURE REVIEW AND HYPOTHESIS}

\section{A. Entrepreneurial Concept}

Entrepreneurship is a creative endeavor that creates value from nothing to something tobe enjoyed by the crowd. Entrepreneurship (entrepreneurship) is the process of creating something new at the value of using the time and effort required, taking on the financial, physical and social risks that 
comes along with it, receiving the resulting monetary rewards, personal satisfaction and freedom.

Entrepreneurs perform a process called creative destruction in order to add a higher value. Therefore, the core of entrepreneurial skills is creativity

\section{B. Self-Efficacy}

Self-efficacy is an individual's beliefs in his ability to perform tasks or actions necessary to achieve certain results [3]. The thought of self-efficacy is generally defined as a belief in the ability to carry out entrepreneurial activity focusing on evaluation of one's managerial, functional and technical abilities [4].

A person with high self-efficacy tends to try harder to overcome challenges in difficult situations, exhibit persistence in confronting obstacles, respond to negative feedbacks by improving effort and motivation, set more challenging goals, and work harder and longer to achieve it. Self-efficacy has been proven useful in predicting the effectiveness of strategies used in managerial decision making [5].

Reference [6] define self-efficacy as an evaluation of one's ability or competence to perform a task, achieve goals, and overcome obstacles. Reference [7] also supported these statements. They describe self-efficacy affects one's belief in the attaining a determined goal. Thus, self-efficacy is a person's self-belief in the ability or competence of himself in performing the tasks required to achieve a certain goal. These dimensions are confidence in the ability to develop new products and market opportunities, confidence to be able to overcome unexpected challenges, confidence to be able to develop existing resources, confidence to be able to define core goals, and confidence in the ability to build relationships with investors

\section{Career Choice}

Regarding career interest, one of the most accepted and validated models is the Social Cognitive Carrier Theory (SCCT) theory. This theory has been the basis of the development of many researches on careers. Reference [8] found that the SCCT model is a very powerful device in predicting the interests and goals of a person to choose entrepreneurship as a career choice.

Reference [1] identifies that one's career choices depends on the personality traits of a person and how one has perceived a particular job. People with high intellectual intelligence sometimes fail to do business. Conversely, there are many people who have relatively lower intellectual level is success in business. Therefore, the level of intellect is not a guarantee of one's success in business.

The career development process is influenced by personality, environment and interrelated situation factors and can change over time [9]. In addition, one of the factors that influence a person's career selection to become an entrepreneur is self-efficacy. The higher the self-efficacy of entrepreneurship owned by a person, the higher the desire to become an entrepreneur, which of course has practical implications for educators [8]

Career selection is a very important choice because of the difficult condition of the current economy. A career plan can be defined as a gradual construction rooted in the past, covering the current state of affairs and passing far ahead, providing an opportunity for the development of one's identity.

\section{Personality}

Individual personalities are attached to individuals whose nature can change over time or stable. Personality is one individual personality that is stable from time to time. "The big five" factor is the most popular concept in dividing the personality dimension.

The concept of personality can be used for several purposes such as: employee or student selection, personality development, team building, personality research, career guidance and learning process [10].

According to The Big five Model, dimensions The Big Five Personality are [11]:

1. Openness to experience: Imaginative, independent, interests in diversity.

2. Conscientiousness: Affinity to be prepared, chary and disciplined

3. Propensity to be gregarious, fun loving, warm is known as extraversion

4. Agreeableness: Tendency to be sympathetic, trusting, supportive

5. Neuroticism: Tendency to be anxious, emotionally unstable and self-blaming

The personality of openness to experience is full of new ideas, active imagination, ingenious and deep, likes selfreflection, curious with many things, innovative, and artistic. Individuals with openness to experience have the opposite personality of the above-mentioned characters such as: not innovative, likes something routine, practical, and narrowminded.

Individuals with high conscientious likes to work hard, according to plan, reliable, routine, careful and detailed, and tend to be diligent. While individuals with low conscientious tent to be more careless, lazy, irregular, and unreliable.

People with high-extraversion or openness to others are most likely to be active, full of energy, enthusiast, firm and definite, friendly and sociable. On the other hand, individuals with low-extraversion tends to be quiet, shy, difficult to get along, and less passionate. Individuals with this personality are also called introversion.

Agreeableness or openness to the agreement has personality such as: cooperative, trustworthy, caring and kind to others, helpful, unselfish, forgiving, and dislike with other 
people. Individuals with these personality are said to have high agreeableness. Conversely, individuals with low agreeableness likes to look for other people's mistakes, happy to quarrel, indifferent, disrespectful, and selfish.

Neo-criticism or openness to stress are often related to feeling depressed, full of tension and anxiety, moody, sad, and easily agitated. Individuals with this personality are said to have unstable emotions but People with this personality can cope with stress well, not easily disappointed, calm in a stressful situation, and not easily depressed.

\section{E. Family Environment}

The environment actually includes all the material and stimulus inside and outside the individual, both physiological, psychological, and socio-cultural [12]. According to another resource, the relation of environment to education can be stated as "The environment can be interpreted, as something that is beyond the child self" [13].

The environment can be anything concrete, like plants, people, circumstances, politics, socio-economic, animal, culture, beliefs, and other efforts undertaken by humans including education. Reference [14] stated that family are:

1. Small social group that generally consists of father, mother and child.

2. The social relationships among family members are relatively fixed and are based on blood, marital and / or adopted bonds.

3. Relationship between families are imbued with an atmosphere of affection and sense of responsibility.

4. The function of the family is to care for, nurture, and protect the child in order for them to gain self-control and social life. Family is a group of people connected by marriage, adoption, births that aim to create and maintain a common culture, enhance the physical, mental, emotional and social development of each family member.

\section{F. Emotional Quotient}

Emotional Quotient is the ability of a person to manage his emotion with intelligence, maintain emotional harmony, and disclosure through self-awareness, self-control, selfmotivation, empathy and social skills. Emotional Quotient consist of 5 dimension, such as:

1. Self-awareness: Aware of own feelings.

2. Self-management: Ability to control emotions and impulses.

3. Self-motivation: Ability to overcome setbacks and failures.

4. Empathy: Ability to feel what others feel.

5. Social skills: Ability to handle others emotion.

\section{G. Creative Intelligence}

Reference [15] mentions creative intelligence is the ability to generate new ideas, solve problems in a unique way and improve imagination, behavior, and productivity. So the assumption that academic genius is the most important capital in achieving success is inappropriate. Everyone has a creative side. Everyone can explore this important element and proofs that intelligence and creativity are two inseparable sides of the coin.

Reference [16] stated that creative intelligence can be classified into 4 dimension:

1. Intuitive

This dimension describes the most resourceful types of individuals and is typical of managers, actors, and politicians. This dimension emphasize on utilizing and relying on past experience guide them in solving problems, achieving results and working hard.

2. Innovative

This dimension describes an inquisitive individual and is typical of scientists, inventors, and engineers. This dimension emphasizes the creativity, experimental and systematic information that concentrates on problems and data and overcomes complexity easily.

3. Imaginative

It depicts an understanding of an individual. This dimension is typical of artists, musicians, writers, and leaders. This dimension is able to detect potential opportunities that can be utilized properly.

4. Inspirational

This dimension is about how a person can see from a positive point of view, oriented to the actions that society needs and willing to sacrifice.

Figure 1. Conceptual Framework

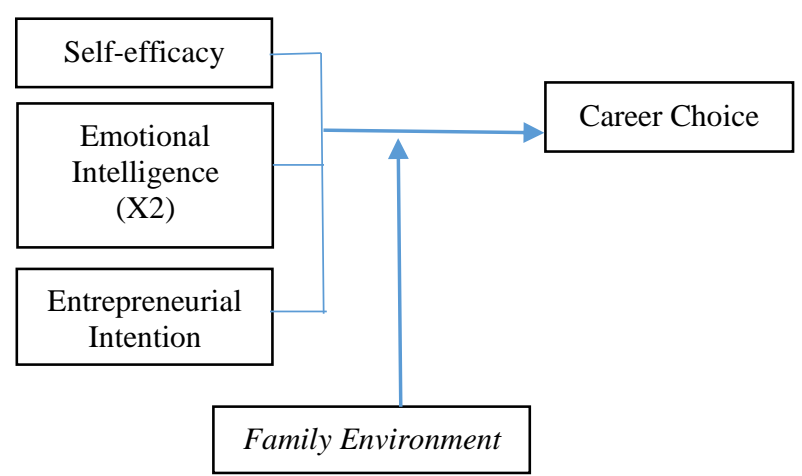

\section{H. Hypothesis}

Based on the description above, the hypothesis of this study are:

1. There are positive and significant correlations between self-efficacy, emotional intelligence, entrepreneurial intention towards career choice of fresh-graduates.

2. Family fully moderates the correlation between selfefficacy, emotional intelligence, and entrepreneurial intention towards career choice of fresh-graduates. 
3. There are correlations between self-efficacy, emotional intelligence, entrepreneurial intention and family towards career choice of fresh-graduates.

\section{METHODOLOGY}

A. Sample and Data Collection

Table 1. Population and Sample

\begin{tabular}{|l|l|c|c|}
\hline No. & University & Students & Sample \\
\hline 1. & University of Sumatera Utara & 645 & 107 \\
\hline 2. & STIE Harapan & 595 & 98 \\
\hline 3. & University of Medan Area & 789 & 129 \\
\hline \multicolumn{2}{|l|}{ Total } & 2029 & 334 \\
\hline
\end{tabular}

The population of this study are 2029 students. The number of samples used in this study after being calculated by Slovin Formula are 334 students.

\section{B. Measures}

\section{Descriptive Statistics Analysis}

Descriptive statistical analysis used in this research to describe the research variables, which are entrepreneurship orientation, business performance, and external business environment. Descriptive statistics are statistics that describe the phenomenon or characteristics of the data. Characteristics of data describes distribution characteristics. This study uses frequency distribution table showing the theoretical range, actual range, mean (mean), standard deviation, mode, and frequency.

\section{Moderated Regression Analysis (MRA)}

Interaction test or commonly known as Moderated Regression Analysis (MRA) is a special application of linear regression multiplication where in the regression equation contains elements of interaction [17]. The criteria of the test are as seen below:

a. $\mathrm{H} 0$ is accepted and $\mathrm{H} 1$ is rejected if $\mathrm{p}$ value $<0.05$ or significance value $>0.05$. It means that the regression model in this study fit for use in this research.

b. $\mathrm{H} 0$ is accepted and $\mathrm{H} 1$ is rejected that if $\mathrm{p}$ value > 0.05 or if significance value $<0.05$. It means that the regression model in this study fit for use in this research.

\section{Absolute Difference Regression}

Reference [17] used the model of the absolute difference value to test the independent variable.

\section{Chi Square Test}

Chi Square test is to test whether there is any association or correlation between one variable with other variables. If Chi-square results show a significance value below 0.05 , then the two variables are proven to be correlated.

\section{Results}

Based on data processing, the result of multiple linear regression analysis as follows:

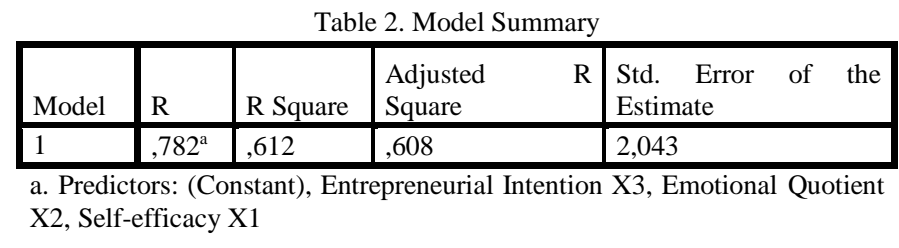

Based on the table above, the adjusted R Square at the time of the moderation variables has not been combined with the initial independent variable, indicating the number of $60.8 \%$. This means that the initial independent variable can $60.8 \%$ predict the dependent variable (career selection) or $39.2 \%$ dependent variable are influenced by other variables that are not stated in this study.

Table 3. ANOVA ${ }^{\mathrm{a}}$

\begin{tabular}{|ll|l|l|l|l|l|}
\hline Model & $\begin{array}{l}\text { Sum } \\
\text { Squares }\end{array}$ & of & $\begin{array}{l}\text { Mean } \\
\text { Square }\end{array}$ & F & Sig. \\
\hline $1 \quad$ Regression & 2102,014 & 3 & 700,671 & 167,953 &, $000^{\mathrm{b}}$ \\
& Residual & 1334,986 & 320 & 4,172 & & \\
\multicolumn{1}{|c|}{ Total } & 3437,000 & 323 & & & \\
\hline
\end{tabular}

a. Dependent Variable: PilKarirY

b. Predictors: (Constant), entrepreneurial intention X3, emotional Quotient $\mathrm{X} 2$, self-efficacy X1

ANOVA table above shows that the significance indicates the number 0.000 , meaning that together the three independent variables can influence the independent variables significantly.

\begin{tabular}{|l|l|l|l|l|l|}
\hline \multicolumn{1}{|c|}{} & \multicolumn{2}{|c|}{ Table 4. Coefficients } \\
& $\begin{array}{l}\text { Unstandardized } \\
\text { Coefficients }\end{array}$ & $\begin{array}{l}\text { Standardized } \\
\text { Coefficients }\end{array}$ & & \\
\cline { 2 - 6 } & B & $\begin{array}{l}\text { Std. } \\
\text { Error }\end{array}$ & Beta & T & Sig. \\
\hline $\begin{array}{l}\text { Model } \\
\text { (Constant) } \\
\text { Self-efficacy X1 }\end{array}$ & 1,674 & 1,150 & & 1,455 &, 147 \\
&, 243 &, 017 &, 600 & 14,000 &, 000 \\
$\begin{array}{l}\text { Emotional } \\
\text { Quotient X2 }\end{array}$ &, 065 &, 022 &, 106 & 2,988 &, 003 \\
$\begin{array}{l}\text { Entrepreneurial } \\
\text { intention X3 }\end{array}$ &, 141 &, 026 &, 233 & 5,480 &, 000 \\
\hline
\end{tabular}

a. Dependent Variable: Career Choice Y

Based on the table above, the coefficient shows that each independent variable partially affects significantly to the dependent variable with the indicated total significance numbers below 0.05 . This means that the influence given to each variables are significant.

Table 5. Model Summary

\begin{tabular}{|l|l|l|l|l|l|}
\hline Model & R & R Square & $\begin{array}{l}\text { Adjusted } \\
\text { Square }\end{array}$ & $\begin{array}{l}\text { Std. Error of the } \\
\text { Estimate }\end{array}$ \\
\hline 1 &, $783^{\mathrm{a}}$ &, 613 &, 608 & 2,043 \\
\hline
\end{tabular}

a. Predictors: (Constant), Family environment Z, emotional Quotient X2, self-efficacy X1, entrepreneurial intention X3 
From the summary model, there is an increase of predictive ability after the inclusion of moderation variable $(\mathrm{Z})$ into the research. Before the inclusion of moderation variables the prediction ability is only $60.2 \%$, but after inserting the adjusted R Square, it becomes $60.8 \%$. Which means there is an increase of about $0.6 \%$ in increasing the prediction of the dependent variable.

Table 6. Coefficients

\begin{tabular}{|c|c|c|c|c|c|}
\hline \multirow[b]{2}{*}{ Model } & \multicolumn{2}{|c|}{$\begin{array}{l}\text { Unstandardized } \\
\text { Coefficients }\end{array}$} & \multirow{2}{*}{$\begin{array}{l}\text { Standardized } \\
\text { Coefficients } \\
\text { Beta }\end{array}$} & \multirow[b]{2}{*}{$\mathrm{t}$} & \multirow[b]{2}{*}{ Sig. } \\
\hline & $\mathrm{B}$ & $\begin{array}{l}\text { Std. } \\
\text { Error }\end{array}$ & & & \\
\hline 1 (Constant) & 2,026 & 1,207 & & 1,678 & ,094 \\
\hline Self-efficacy X1 &, 244 & ,017 & ,602 & 14,031 & ,000 \\
\hline $\begin{array}{l}\text { Emotional } \\
\text { Quotient X2 }\end{array}$ &, 064 & ,022 &, 104 & 2,937 & ,004 \\
\hline $\begin{array}{l}\text { Entrepreneurial } \\
\text { Intention X3 }\end{array}$ &, 150 & ,027 & ,248 & 5,482 &, 000 \\
\hline $\begin{array}{l}\text { Family } \\
\text { Environment Z }\end{array}$ &,- 018 & ,019 &,- 037 &,- 962 & ,337 \\
\hline
\end{tabular}

a. Dependent Variable: Career Choice Y

From the coefficient table, the three independent variables show a significant influence (sig <0.05). As for the significance of variable $\mathrm{Z}$ (moderation) indicates an insignificant number (Sig $>0,05)$. This suggests that the moderating variable may be the moderator for the dependent variable, but it is not yet certain whether the moderator is pure or quarsi moderator. It must be further tested through the interaction variable (multiplication) between each independent variable and the moderating variable $(\mathrm{Z})$.

\begin{tabular}{|l|l|l|l|l|}
\hline \multirow{2}{*}{ Model } & R & R Square & Adjusted R Square & $\begin{array}{l}\text { Std. Error of the } \\
\text { Estimate }\end{array}$ \\
\hline 1 &, $819^{\mathrm{a}}$ &, 672 &, 664 & 1,890 \\
\hline
\end{tabular}

a. Predictors: (Constant), X3.Z, IntuisiX2, EfikasiX1, KreatifX3, X2.Z, LingkelZ, X1.Z

From the table above, the interaction of independent variables with moderation increases the predictive ability to $66.4 \%$ from $60.8 \%$ before the inettraction variable. This shows that the prediction variable can improve predictor's ability by $5.4 \%$ compared to before the interaction between independent variables without moderation.

The table below shows that the moderating variables still remain insignificant. If after the moderation and interaction variables are incorporated into the research model and the significance for the moderation variable is still not significant while the variable inettraction is significant, it is certain that the moderation variable is pure moderator [17].
Table 8. Coefficients ${ }^{\mathrm{a}}$

\begin{tabular}{|c|c|c|c|c|c|}
\hline \multirow[b]{2}{*}{ Model } & \multicolumn{2}{|c|}{$\begin{array}{l}\text { Unstandardized } \\
\text { Coefficients }\end{array}$} & \multirow{2}{*}{$\begin{array}{l}\text { Standardized } \\
\text { Coefficients } \\
\text { Beta }\end{array}$} & \multirow[b]{2}{*}{$\mathrm{t}$} & \multirow[b]{2}{*}{ Sig. } \\
\hline & B & $\begin{array}{l}\text { Std. } \\
\text { Error }\end{array}$ & & & \\
\hline 1 (Constant) & $-6,620$ & 4,709 & & $\begin{array}{l}- \\
1,406\end{array}$ &, 161 \\
\hline Self-efficacy X1 & ,604 & 081 & 1,489 & 7,443 &, 000 \\
\hline $\begin{array}{l}\text { Emotional } \\
\text { Quotient X2 }\end{array}$ &, 257 & ,078 & ,418 & 3,292 & ,001 \\
\hline $\begin{array}{l}\text { Entrepreneurial } \\
\text { Intention X3 }\end{array}$ &,- 429 & ,094 &,- 710 & - &, 000 \\
\hline $\begin{array}{l}\text { Family } \\
\text { Environment Z }\end{array}$ &, 179 &, 121 & ,370 & 1,480 &, 140 \\
\hline $\mathrm{X} 1 . \mathrm{Z}$ &,- 008 & ,002 & $-1,475$ & - &, 000 \\
\hline $\mathrm{X} 2 . \mathrm{Z}$ &,- 004 & ,002 &,- 482 & $-\overline{2,504}$ & ,013 \\
\hline X3.Z &, 013 & ,002 & 1,586 & 5,986 &, 000 \\
\hline
\end{tabular}

\section{CONCLUSION AND LIMITATIONS}

Based on the results of the analysis and discussion done in this study, the conclusions are:

1. Self-efficacy has a positive and significant effect on career selection

2. Emotional Intelligence has a positive and significant effect on career selection

3. Entrepreneurial intention has a positive and significant effect towards career selection

4. Family environment is a variable that moderate selfefficacy variables, emotional intelligence, entrepreneurship intentions to career selection variables

\section{References}

[1] Bradberry, T., 2007. The Personality Code, New York : Putnam

[2] Muhdiyanto, Luklun Atul Hidayati. (2013), Efek Moderasi Self Efficacy pada Pengaruh Kecerdasan Emosional Terhadap Perilaku Kewarganegaraan Organisasional : Studi Empiris di Lembaga Perbankan Bukan Bank di Magelang. Magelang : Jurnal Fakultas Ekonomi Universitas Muhamadiyah magelang, Vol 15, No 1, Hal 19

[3] Bandura, A. (2003), Self-efficacy: The Exercise of Control, Freeman, New York, NY

[4] Naktiyok, Atilhan., Canan Nur Karabey., dan Ali Caglar Gulluce. 2009. "Entreprenuerial Self-Efficacy and Entreprenuerial Intention: in Turkey Case". Springer Science + Business Media, LLC

[5] Punnett, Betty Jane., Nurse Lawrence., Duffy, Jo Ann., Fox, Suzy., Gregory, Ann., Lituchi, Terri., Monserrat, Silvia Ines., Olivas-Lujan, Miguel. R., dan Santos, Neusa Maria Bastos.F. 2007. "Professionally Successful Women: Some Evidence from The English-Speaking Caribbean". Canadian Journal of Latin American \& Caribbean Studies, Vol.32, No.64

[6] Baron, R.A., \& Byrne, D. (1991), Social Psychology : Understanding Human Interactioms (6th Ed), Boston, MA : Allyn Bacon

[7] Indarti, N. Dan Rokhima Rostiani. 2008. "Intensi Kewirausahaan Mahasiswa: Studi Perbandingan antara Indonesia, Jepang dan Norwegia" Jurnal Ekonomika dan Bisnis Indonesia, Vol. 23, No. 4, Hal 24.

[8] Segal G, Schoenfeld J, Borgia D. (2007), Which Classroom-Related Activities Enhance Students' Entrepreneurial Interests and Golas?: A 
Social Cognitive Career Theory Perspective. Academy of Entrepreneurship Journal 13(2) pg.79.

[9] Robert W. Lent and Gail Hackett. Contextual Supportsnand Barriers to career choice : A Social Cognitive Analysis. Journal of Counseling Psychology 2000, Vol 47, no.1, 36-49

[10] Stanton.N and Matthews. G. (1995), Twenty-one traits of personality : An Alternative Solution for the Occupational Personality Questionnaire, Journal of Management Development, Vol : 14, Issue : 7, pp 66-75

[11] John, O.P., Donahue, E.M., \& Kentle, R.L. (1991). The Big Five Inventory-Version 4a and 54. Berkely, CA : University of California, Berkeley, Institue of Personality and Social Research.
[12] Dalyono. (2009). Psikologi Pendidikan. Jakarta : Rineka Cipta

[13] Ihsan, Duad. (2007). Dasar-Dasar Kependidikan. Jakarta : Rineka Cipta

[14] Khairuddin. (2008). Sosiologi Keluarga. Yogyakarta : Liberty

[15] Buzan, Tony 2002, The Power Of Creative Intelligence, Perfect Bound Harpercollins Publisher, New York

[16] Rowe, A.J. 2004. Creative Intelligence: Membangkitkan Inovasi Dalam Diri dan Organisasi Anda. Bandung: Kaifa.

[17] Ghozali, Imam, 2013. Aplikasi Analisis Multivariate Dengan Program IBM SPSS 23 Edisi 8, Universitas Diponegor, Semarang 